\title{
The Mediating Effect of Organizational Commitment in the Impact of Transformational Leadership Style on Employee Performance: A Study of Divisional Secretariats in the Jaffna District
}

\author{
Thaneswary Raveendran (corresponding author) \\ Senior Lecturer \& Head \\ Department of Human Resource Management \\ University of Jaffna, Sri Lanka. \\ E-mail: rthanes67@gmail.com \\ Aruna Shantha Gamage \\ Professor, \\ Department of Human Resource Management, \\ University of Sri Jayewardenepura, \\ Colombo, Sri Lanka \\ E-mail: arunasgamage@gmail.com
}

Received: Feb. 17, 2019 Accepted: Mar. 18, 2019 Online published: Apr. 7, 2019

doi:10.5296/ijhrs.v9i2.14623 URL: https://doi.org/10.5296/ijhrs.v9i2.14623

\begin{abstract}
The purpose of this study is to examine the mediating effects of organizational commitment on the relationship between transformational leadership style and employees' job performance in the Divisional Secretariats in Jaffna District. 287 employees were selected for this study. Leadership styles were measured using MLQ Rater Form 5-x, employee performance was measured using job performance Scale and organizational commitment was measured using Organizational Commitment Questionnaire. Exploratory factor analysis was performed to get factor structure and confirmatory factor analysis performed to confirm the validly and reliability of the study instruments. The results revealed that transformational
\end{abstract}


leadership has a positive impact on job performance and on organizational commitment. It was also found that organizational commitment doesn't have a mediating effect in the impact of transformational leadership on employee performance. The findings also revealed that organizational commitment doesn't have impact on employee performance. This study recommends that the leaders should pay more attention in their leadership style as a way to improve employee performance. This study further suggests that future researchers should cover larger samples and the other public sector organizations to better understand the relationship between the variables.

Keywords: divisional secretariats, job performance, organizational commitment and transformational leadership

\section{Introduction}

Effective leadership by superiors and managers is one of the most important aspects of improving performance of employees. The leaders play a critical role in achieving higher productivity of the organizations as they are in charge of directing all the employees to achieve organizational goals. Thus, to strengthen the productivity of the organizations, the capabilities of managers and leaders have to be developed continuously and systematically. If an organization wants to improve the productivity, it should look for the ways to develop leaders to make them adopt appropriate leadership style. In addition, the organizations need identify the ineffective leaders who don't adopt appropriate leadership style or who don't change their style and, should take steps to develop necessary skills for them. Thus, the present study attempts to investigate the effects of transformational leadership on employee performance and the mediating effect of organizational commitment in the effect of transformational leadership on employee performance.

It is commonly accepted that the effectiveness of people in any job is largely dependent on the quality of their superiors' leadership and the leader behaviour facilitates fulfillment of the followers' expectations and desires which results increased performance. A number of studies examined the effects of leadership styles on employee performance (for example, Rasool, Arfeen, Mothi, \& Aslam, 2015; Pradeep and Prabhu, 2011; Aboshaiqah, Hamdan-Mansour, Sherrod, Alkhaibary, \& Alkhaibary, 2015; Tsigu \& Rao, 2015; Ispas, 2012; Gimuguni, Nandutu, \& Magolo, 2014; and Raja \& Palanichamy, 2015). Many researchers have examined the relationship between autocratic, democratic and laissez-faire leadership and performance of employees. For example, Gimuguni et al. (2014) reported positive relationship between autocratic, democratic and laissez-faire leadership and performance and, Ispas (2012) reported that autocratic leadership to be the most used style in the hotel industry and it is perceived as appropriate style that results in positive outcomes.

There is no shortage of literature in the field of leadership, however, the studies investigating transformational leadership and performance in the Sri Lankan context, especially in the Jaffna District, is very rare. Thus the focus of the current study is to investigate the relationship among the variables in the Jaffna context. 


\section{Objective}

Although leadership styles have been extensively studied, there is little evidence about the mediating effect of organizational commitment on the relationship between leadership style and employee performance (Yousef, 2000; and Yeh \& Chien, 2012). It is rare to come across the studies on these variables, particularly in the Jaffna context where the people's culture differs considerably. Thus, the objective of the present study is to investigate the mediating effect of organizational commitment in the impact of transformational leadership on job performance of employees of Divisional Secretariats in the Jaffna District.

\section{Research Problem}

There is a problem of gross mismanagement of the public interest $\mathrm{n}$ the current Sri Lankan public sector. The largest employee group in our country has the least concern for employee productivity (Wijesiri, 2016). People expect the public service to be more effective and transparent. Sri Lankans continue to rely on public service to satisfy most of their needs, however, they are increasingly distrustful of its performance. If the managers and leaders better manage the employees, it is possible to move toward a productive workforce and to meet the common expectations of the people.

The problem focused in the present study is:

\section{'The largest employee group in the Divisional Secretariats shows the least concern for work performance'.}

\section{Research Gap}

There has been considerable empirical research on leadership in different sectors in various countries (for example, Basham, 2012; Bolden, Gosling, O’Brien, Peters, Ryan, \& Haslam, 2012; Herbst \& Conradie, 2011; Lopez-Dominguez, Enache, Sallan, \& Simo, 2014; Sani \& Maharani, 2012; Vinger, 2009). However, these studies have varied widely in terms of context, objective and methods used. Particularly, two recent meta-analyses by Gottfredson and Aguinis (2017) and Ng (2017) revealed the relationship between transformational leadership and performance related outcomes. However, those two meta-analyses failed to address organizational commitment as mediator in the relationship between transformational leadership and employees' performance. The current study provides an insight of the relationship between these variables by including organizational commitment as the potential mediator.

Chan (2010) pointed that several researchers who investigated leadership styles have not come up with a specific style suitable for specific situation. He suggests that different styles are needed for different situations and leaders need to understand which style would fit to the situation. The culture and context could be the situational aspects and thus studying the effects of leadership styles on performance in the context of Jaffna is useful to add knowledge to the existing literature.

Furthermore, previous researchers have studied different types of leadership theories such as autocratic and democratic leadership, task and people oriented leadership, directive and 
supportive leadership etc. For example, Hemakumara (2011) investigated the relationship between the directive and supportive leadership styles and team cohesiveness in the public sector organizations in Sri Lanka. There is a gap in the current literature examining the effects of transformational leadership style on employee performance in the Sri Lankan context.

\section{Research Questions}

Based on the theoretical notions and findings discussed above, this research has been designed to address the following questions:

1. What is the influence of perceived transformational leadership on employees' performance in the Divisional Secretariats in the Jaffna District?

2. To what extent organizational commitment mediates the effects of transformational leadership on employees' performance in the Divisional Secretariats in the Jaffna District?

\section{Review of Literature}

\subsection{Leadership}

According to Jong and Hartog (2007), leadership can be defined as a process of influencing to get the desired outcomes. Leadership is the process whereby one individual influences others to willingly and enthusiastically direct their efforts and abilities towards attaining defined group and organizational goals ( Nel et al. 2004). According to Cole (2005), leadership is a dynamic process whereby one person influences others to contribute for attaining goals and objectives. The leadership facilitates an organization or a group to attain sustainable development. Anderson (2004) has pointed out that leaders stimulate, motivate and recognize their employees to get work done and to achieve expected results. Leadership styles adopted by leaders encourage positive behaviours among employees. Lok and Crawford (2004) stated that leadership can better predict the success or failure of an organization.

\subsection{Transformational Leadership}

The concept of transformational leadership was first introduced by leadership expert and presidential biographer James Macgregor Burns. According to Burns (1978), transformational leadership can be seen when the leaders and followers make each other to advance to a higher level of moral and motivation. Transformational leaders are able to inspire followers, change their perceptions and motivate them to work for attaining common goals. Burnad M.Bass expanded upon Burn's original ideas to develop the theory named as Bass' Transformational Leadership Theory.

Transformational leadership is related to rejuvenate something. It can be described as a process that changes and transforms individuals through influencing and encouraging them to accomplish more than what is usually expected. Transformational leadership is mainly concerned with emotions, values, ethics, standards and long term goals. Transformational leaders try to develop a vision for future and mobilize followers to create a change and to 
achieve results beyond the expectation. The concept of transformational leadership can be an effective style when there is a need for responding to dynamic environment which involves transformations in organizations. In the competitive and ever-changing environment, organizational leaders need to direct their organization to find new opportunities and face challenges in the environment. The concept of transformational leadership is vital in the light of the challenges we face ahead and as well in the actual leadership tasks (Avolio \& Yammarino, 2002). Transformational leadership style has been suggested by many researchers as the optimum style for the Managing change.

Bass, Waldman, Avolio, and Bebb (1987) discovered that leaders scoring higher on transformational leadership dimensions have followers who display much transformational behaviour. Based on empirical research, Bass (1985) and later Avolio, Bass and Jung (1999), Bass and Avolio (1990), and Hater and Bass (1988) have proposed the five dimensions of transformational leadership: inspirational motivation, idealized influence (attributes), idealized influence (behavior), intellectual stimulation and individualized consideration. Inspirational motivation is the articulation and representation of vision by the leaders by viewing the future with positive attitude. As a result followers are inspired and motivated. Idealized influence (attributed), refer to the attribution of charisma to the leaders. Because of leader's positive attributes, followers built close emotional ties to the leaders. Idealized influence (behaviour) refers to giving emphasis on collective sense of mission and values. Idealized influence and inspirational motivation are often related to charismatic leadership. Intellectual stimulation includes challenging the assumption of followers' beliefs, the analysis of problems they face and solution they generate. Individualized consideration is related to considering individual needs and goals of followers and developing them.

\subsection{Employee Performance}

Employee performance is said to be a multidimensional construct (Befort \& Hattrup, 2003). This has induced both practitioners and researchers to identify the dimensions of employee performance with the aim of managing the performance in the organizations. Role-based model of performance is said to be widely accepted method of conceptualization of employee performance (Welbourne, Johnson, \& Erez, 1998). Role of employees on the job is central to the effectiveness of the organization and thus the role should be considered when measuring employee performance.

Though various models are available in human resource management for assessing employee performance, the task and contextual performance model (Motowidlo \& Van Scotter, 1994) and the role based model of performance (Welbourne, Johnson,Erez,1998) are said to be highly accepted model of performance. Dammika (2013) tested these two models to identify the best model for measuring the performance of employees in the public sector in Sri Lanka. He found that the five factor model (job, career, innovator, team and organization role) is more suitable for the assessment of employees' performance in the public sector. Similar findings have been reported in the study of Wallace, Edward, Arnorld and Frazier (2009). The five factor model confines the five roles in a job that constitute overall performance of employees. 


\subsection{Organizational Commitment}

Employee' organizational commitment is defined as the degree of identification and involvement that individuals have with their organization's mission, values and goals. It comprises affective commitment, normative commitment and continuance commitment. Meyer and Allen (1997) define affective commitment as the employee's emotional attachment to identification with and involvement in the organization; continuance component is defined as commitment that is based on the cost that the employee associates with leaving the organization; normative component is defined as the employee's feeling of obligation and sense of loyalty to remain with the organization and serve to the best of his potential.

\subsection{Empirical Evidence}

\subsubsection{Transformational Leadership and Employee Performance}

Research studies have reported positive relationship between transformational leadership and task performance (e.g., Liao \& Chuang, 2007: MacKenzie, Podsakoff,\& Rich, 2001). Transformational leadership has been linked with task performance, contextual performance and creative performance (Gong, Huang, \& Farh, 2008: Shin \& Zhou, 2007). In addition, transformational leadership is related not only to individual performance but also group and organizational level performance (Bass, 1985: Conger \& Kanungo, 1998: Shamir, House, \& Arthur, 1993). Transformational leadership motivates followers to work hard exerting more effort. According to Podsakoff, MacKenzie, and Bommer (1996), transformational leadership motivates employee to work beyond the requirement of their job descriptions and thus they demonstrate contextual performance.

Researchers have reported that transformational styles are significantly and positively correlated with employee performance (Kehinde \& Banjo, 2014; Pradeep \& Prabhu, 2011; Tsigu \& Rao, 2012; Gimuguni et al., 2014 and Rassol et al., 2015). Aboshaiqah et al (2015) also investigated the connection between leadership style and employee performance among hospital nurses and report that the transformational and transactional leadership styles have significant positive relationship with employee performance. Pradeep and Prabhu (2011) reported a significant positive relationship between transformational and transactional leadership style and employee performance. Tsigu and Rao (2012) investigated Ethiopian banking industry and reported that transformational leadership explained more variation in employee performance than transactional leadership style. Transformational leaders give confidence to their followers that they can achieve the goal set for them (Sharmir et al., 1993). Furthermore, transformational leaders play the role of mentors to their followers and support them to complete their tasks (Howell \& Hall-Merenda, 1999). Employees are motivated and inspired by transformational leaders to complete their assigned task as they connect the followers' work role with the vision of the organization and, as a result, the followers view their work as significant one (Bono \& Judge, 2003; Zhu, Avolio, \& Walumbwa, 2009).

\subsubsection{Transformational Leadership and Organizational Commitment}

Many researchers have reported that the transformational leadership is directly related with 
organizational commitment (Abdul, Ausnain \& Munawae, 2012; Greenburg \& Baron, 2009; and Bass \& Avolio, 1994). Lo Ramayah and Min (2009) examined leadership styles and employees' organizational commitment in Malaysian manufacturing industry. They discovered that many subscales of transformational leadership have positive relationship with organizational commitment. In several studies, it was confirmed that dimensions of organizational commitment are positively influenced by transformational leadership style (Wayne et at., 2000; Dvir et al ., 2002; Avolio, Zhu, \& Puja, 2004; Barbuto, 2005; and Thamrin, 2012).

\subsubsection{Organizational Commitment and Employee Performance}

Researcher found a positive relationship between organizational commitment and employee' job performance (Chen, Silverthrone \& Hung, 2006). Based on the study of 202 managers in Malaysian companies Rashid, Sambasvani, and Joari (2003) have suggested that organizational commitment has an impact on performance. Considering the empirical evidences, it is apparent that there is relationship between employees' organizational commitment and their job performance.

7.5.4 Mediating Effect of Organizational Commitment in the Effect of Transformational Leadership on Employee Performance

Leadership style and organizational commitment positively affect employees' performance. Yeh and Hong (2012) found that organizational commitment partially mediates the relationship between leadership style and job performance. Chi, Tsai and Chang (2007) also reported that organizational commitment fully mediates the relationship between leadership style and job performance. Yiing, Zaman and Ahmad (2009) found that leadership style affects organizational commitment, but organizational commitment does not influence employee' job performance. From their finding it can be said that organizational commitment doesn't mediate the relationship between leadership style and employee performance.

\section{Methodology}

\subsection{Conceptual Framework}

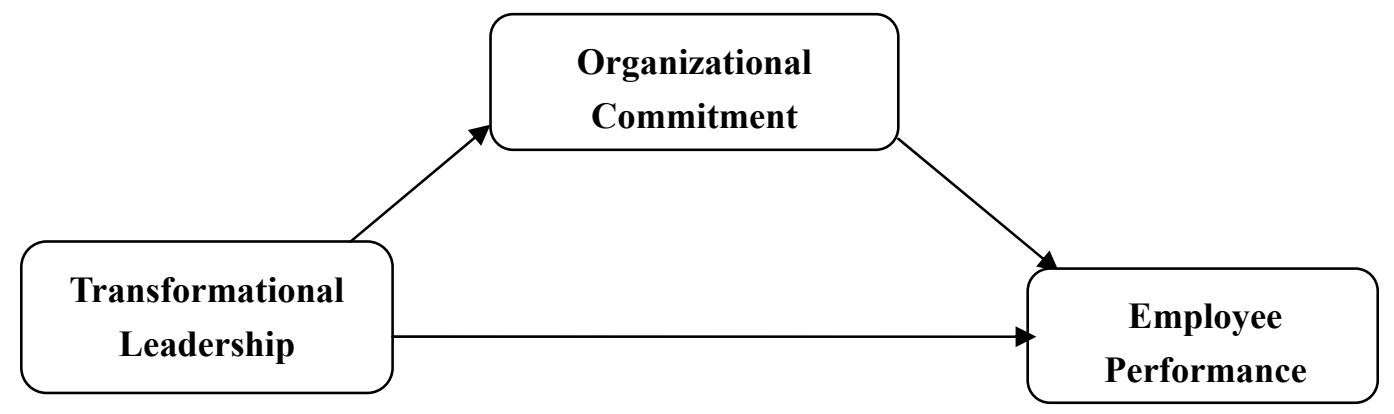

Figure 1. The conceptual framework

\subsection{Hypotheses}

Based on the review of literature, the following hypotheses were formulated in the present study. 
H1: Transformational leadership has a significant positive impact on employee performance

H2: Transformational leadership has a significant positive impact on organizational commitment

H3: Organizational Commitment has a significant positive impact on employee performance

H4: Organizational Commitment has a mediating effect in the impact of transformational leadership on employee performance.

\subsection{Sampling}

There are 15 Divisional Secretariats operating in Jaffna district. Out of these, the samples were selected from 10 Divisional Secretariats using multi-stage sampling technique. The study covers Divisional Secretariats and Vidatha Centers and Divineguma Praja Moola Banks which operate under the Divisional Secretariats. The categories of staff working in these institutions include staff grade, combined services grade and minor grade. Among these, employees from the combined services grade were taken for the study. Thus the population of interest includes employees of combined services grade who are employed in the Divisional Secretariats in the Jaffna District. The combined services grade employees play major role in fulfilling the requirements of the public in the respective region and interact much with the public. The performance of this category of employees is influenced by the leadership style adopted by their immediate superiors. Therefore, to ensure high quality of public service, the leadership-performance relationship should be identified among the employees of combined services category.

Of the organizations approached to participate, a sample of 294 employees from combined services grade, constituting $25 \%$ of the population (population size-1225), participated in the present study. The sample size is adequate to represent the population according to Sekaran's (1992) sample size requirement. In the data collection process, participants were randomly selected from each department/ unit and were requested to gather in the conference hall of the respective institution with the permission of the respective heads of institutions/ departments/ units and questionnaires were distributed to the participants. The method ensured that there was a $100 \%$ response rate and that all questionnaires were completed. Of those distributed, 7 questionnaires were incomplete and thus rejected.

\subsection{Instruments}

The present study employs survey method and questionnaires were used to collect data from the research participants. The instruments were pretested before administering. A brief description of the constructs/ instruments used in the study is given below.

Leadership style: The moderated Multifactor Leadership Questionnaire (MLQ), Form 5-x (rater form) developed by Bass and Avolio (2000) was used to measure the transformational leadership. The MLQ form 5-x is a 45 item questionnaire which is used to measure transformational, transactional and laissez-fire leadership styles. In the current study, only 20 items of MLQ which are related to transformational leadership were extracted. The items are rated using a 5-point Likert scale with anchors labeled as 1= not at all, 2= once in a while, $3=$ 
sometimes, $4=$ fairly often, $5=$ frequently, if not always.

Employee Performance: Employee Performance measure was adopted from 20 items of self rating instrument of Welbourne, Johnson and Erez (1998). They identified five roles of performance namely job role, career role, innovator role, team role and organization role behaviour. The five factor model of performance of Welbourne, Johnson and Erez (1998) is largely validated (Dhammika, 2013) and thus was used in the current study. Each of the items are rated using a 5-point Likert scale with anchors labeled: $1=$ very low, $2=$ low, $3=$ average, 4= high, $5=$ very high.

Organizational Commitment: The Organizational Commitment questionnaire (OCQ) developed by Meyer and Allen (1997) was used to measure commitment of employees. This is aself scoring questionnaire containing 18 items. Responses to the items are rated using a 5 -point Likert scale with anchors labeled as $1=$ strongly disagree, $2=$ disagree, $3=$ neither agree nor disagree, $4=$ agree, $5=$ strongly agree

In the present study, before the actual administration of the questionnaire to the participants, the instruments were pretested with 20 employees generated by convenience sampling to ensure the validity of the instruments. Respondents were asked to fill out the survey and give feedback of the survey in terms of wording, clarity of theme, and format. Based on the respondents' feedback, the items were reworded or modified to avoid ambiguity and confusion.

\section{Results}

Data analysis was conducted using SPSS 20.0 for Windows and AMOS 18.0 software. A significance level of $\mathrm{p}<.05$ will be used for all statistical tests performed. The proposed model and hypotheses were tested with structural equation modeling (SEM) which includes Factor Analysis using AMOS, Correlation and Regression were carried out using SPSS.

Table 1. Demographic profile of the sample

\begin{tabular}{l|l|r|r}
\hline \multicolumn{2}{c|}{ Category } & Frequency & Percentage \\
\hline Gender & Female & 184 & 64.1 \\
\hline & Male & 103 & 35.9 \\
\hline & Total & 287 & 100.0 \\
\hline Age & Below 25 & 8 & 2.8 \\
\hline & $26-35$ & 111 & 38.7 \\
\hline & $36-45$ & 148 & 51.5 \\
\hline & 46 and above & 20 & 7.0 \\
\hline & Total & 287 & 100.0 \\
\hline Civil status & Married & 231 & 80.5 \\
\hline & Unmarried & 56 & 19.5 \\
\hline & Total & 287 & 100.0 \\
\hline Educational & A/Level & 48 & 16.7 \\
\hline & & &
\end{tabular}




\begin{tabular}{l|l|r|r}
\hline & Diploma & 13 & 4.5 \\
\hline & Degree & 181 & 63.1 \\
\hline & PG Diploma & 22 & 7.7 \\
\hline & Master Degree & 23 & 8.0 \\
\hline & Total & 287 & 100.0 \\
\hline & Below 5 years & 129 & 44.9 \\
\hline & 6-10 years & 50 & 17.5 \\
\hline & $11-15$ years & 67 & 23.3 \\
\hline & $16-20$ years & 28 & 9.8 \\
\hline & Above 20 years & 13 & 4.5 \\
\hline Position & Total & 287 & 100.0 \\
\hline & Managerial & 78 & 27.2 \\
\hline & Non-managerial & 209 & 72.8 \\
\hline & Total & 287 & 100.0 \\
\hline
\end{tabular}

The study employed exploratory factor analysis (EFA) to identify the factors of transformational leadership, organizational commitment and employee performance with Principal Component Analysis (PCA) extraction method and Promax Rotation Method. Field (2013) recommends using either direct oblimin or promax rotation with the default parameter settings. Each latent construct was run separately with its sub-constructs.

In Exploratory Factor Analysis, the Kaiser-Meyer-Olkin measure of sampling adequacy (KMO) is .861, exceeding the minimum recommended value of 0.7 and the Bartlett's Test of Sphericity is 1653 , which is significant $(\mathrm{p}=.000)$. No multicollinearity exist between the items as the Determinant value is greater than 0.0001 . The factors extracted through EFA for the latent constructs transformational leadership, employee performance and organizational commitment are shown in Table 2, 3 and 4 respectively. To assess the scales' reliability, the Cronbach's alpha values were studied. The Cronbach's alpha for all the scales exceeded the critical limit of $70 \%$ (Nunnally, 1978)

Table 2. Factor loadings for the constructs of Transformational leadership

\begin{tabular}{l|r|r|l|r|r|c}
\hline & \multicolumn{5}{|c|}{ Component } & \\
\cline { 2 - 6 } & $\begin{array}{l}\text { Individualized } \\
\text { Consideration }\end{array}$ & $\begin{array}{c}\text { Intellectual } \\
\text { Stimulation }\end{array}$ & $\begin{array}{c}\text { Inspirational } \\
\text { Motivation }\end{array}$ & $\begin{array}{c}\text { Idealized } \\
\text { Influence- } \\
\text { Behaviour }\end{array}$ & $\begin{array}{c}\text { Idealized } \\
\text { Influence- } \\
\text { Attributes }\end{array}$ & $\begin{array}{c}\text { Cronbach's } \\
\text { Aplpha }\end{array}$ \\
\hline IN_CO2 & .893 & & & & & $\mathbf{0 . 7 5 9}$ \\
\hline IN_CO4 & .777 & & & & & \\
\hline IN_CO1 & .764 & & & & & \multirow{2}{*}{$\mathbf{0 . 7 0 2}$} \\
\hline IN_ST4 & & .696 & & & & \\
\hline IN_ST2 & & .613 & & & & \\
\hline IN_ST1 & & .585 & & & & $\mathbf{0 . 7 4 6}$ \\
\hline IN_ST3 & & .579 & & & & \\
\hline IN_MO1 & & & .816 & & & \\
\hline
\end{tabular}




\begin{tabular}{|c|c|c|c|c|}
\hline IN_MO3 & .793 & & & \\
\hline IN_MO2 & .754 & & & \\
\hline ID IN B4 & & .781 & & \multirow[t]{2}{*}{0.749} \\
\hline ID_IN_B1 & & .768 & & \\
\hline ID_IN_A2 & & & .711 & \multirow[t]{3}{*}{0.706} \\
\hline ID_IN_A1 & & & .637 & \\
\hline ID_IN_A4 & & & .629 & \\
\hline
\end{tabular}

Source : Survey Data, 2018

Table 3. Factor loadings for the construct of Employee Performance

\begin{tabular}{|c|c|c|c|c|c|c|}
\hline & \multicolumn{5}{|c|}{ Component } & \multirow[b]{2}{*}{$\begin{array}{c}\text { Cronbach's } \\
\text { Alpha }\end{array}$} \\
\hline & Career Role & Team Role & $\begin{array}{c}\text { Organizatio } \\
\text { n Role }\end{array}$ & Job Role & $\begin{array}{c}\text { Innovator } \\
\text { Role }\end{array}$ & \\
\hline P_CAR1 & .891 & & & & & \multirow[t]{4}{*}{0.899} \\
\hline P_CAR3 & .844 & & & & & \\
\hline $\mathrm{P} \_\mathrm{CAR} 2$ & .828 & & & & & \\
\hline P_CAR4 & .751 & & & & & \\
\hline $\mathrm{P}_{-} \mathrm{TM} 3$ & & .943 & & & & \multirow[t]{4}{*}{0.841} \\
\hline $\mathrm{P}$ _TM4 & & .822 & & & & \\
\hline $\mathrm{P}_{-} \mathrm{TM} 2$ & & .684 & & & & \\
\hline $\mathrm{P}_{\text {_TM1 }}$ & & .672 & & & & \\
\hline P_ORG3 & & & .962 & & & \multirow[t]{3}{*}{0.906} \\
\hline $\mathrm{P} \_$ORG2 & & & .916 & & & \\
\hline P_ORG4 & & & .798 & & & \\
\hline P_JOB1 & & & & .812 & & \multirow[t]{4}{*}{0.785} \\
\hline P_JOB3 & & & & .804 & & \\
\hline P_JOB2 & & & & .790 & & \\
\hline P_JOB4 & & & & .586 & & \\
\hline P_INO3 & & & & & .772 & \multirow[t]{2}{*}{0.824} \\
\hline P_INO1 & & & & & .667 & \\
\hline
\end{tabular}

Source: Survey Data, 2018

Table 4. Factor loadings for the construct of Organizational Commitment

\begin{tabular}{l|r|c|c|c}
\hline & \multicolumn{3}{|c|}{ Component } & \\
\cline { 2 - 4 } & $\begin{array}{c}\text { Normative } \\
\text { Commitment }\end{array}$ & $\begin{array}{c}\text { Affective } \\
\text { Commitment }\end{array}$ & $\begin{array}{c}\text { Continuance } \\
\text { Commitment }\end{array}$ & $\begin{array}{c}\text { Cronbach's } \\
\text { Alpha }\end{array}$ \\
\hline OC_NO4 & .843 & & & \multirow{2}{*}{$\mathbf{0 . 8 8 7}$} \\
\cline { 1 - 3 } OC_NO5 & .839 & & & \\
\hline OC_NO6 & .786 & & & \\
\hline OC_NO3 & .756 & & & \\
\hline OC_NO2 & & &
\end{tabular}




\begin{tabular}{|c|c|c|c|c|}
\hline OC_NO1 & .734 & & & \\
\hline OC_AF3 & & .875 & & \multirow[t]{4}{*}{0.850} \\
\hline OC_AF2 & & .840 & & \\
\hline OC_AF5 & & .834 & & \\
\hline OC_AF1 & & .759 & & \\
\hline OC_CON6 & & & .763 & \multirow[t]{5}{*}{0.714} \\
\hline OC_CON4 & & & .706 & \\
\hline OC_CON2 & & & .685 & \\
\hline OC_CON1 & & & .635 & \\
\hline OC_CON5 & & & .619 & \\
\hline
\end{tabular}

Source : Survey Data, 2018

As can be seen in Table 5, the cumulative percentage of variance explained was adequate as variance explained by the sub-constructs of each factor exceed the minimum requirement of $50 \%$. According to the Table 5, the variance is explained by the sub-constructs of transformational leadership, employee performance and organizational commitment are $65.1 \%, 74.4 \%$ and $61.04 \%$ respectively. Thus further analysis could be carried out to confirm the validity.

Table 5. Eigen value and variance explained

\begin{tabular}{|c|c|c|c|}
\hline Factor & $\begin{array}{c}\text { Percentage } \\
\text { of Variance } \\
\text { explained }\end{array}$ & $\begin{array}{l}\text { Cumulative } \\
\text { percentage of } \\
\text { variance } \\
\text { explained }\end{array}$ & $\begin{array}{l}\text { Number } \\
\text { of items } \\
\text { retained }\end{array}$ \\
\hline \multicolumn{4}{|l|}{ Transformational Leadership } \\
\hline Individualized Consideration & 33.012 & 33.012 & 3 \\
\hline Intellectual Stimulation & 12.249 & 45.261 & 4 \\
\hline Inspirational Motivation & 7.112 & 52.374 & 3 \\
\hline Idealized Influence- Behaviour & 6.695 & 59.068 & 2 \\
\hline Idealized Influence- Attributes & 6.032 & 65.101 & 3 \\
\hline \multicolumn{4}{|l|}{ Employee Performance } \\
\hline Career Role & 45.723 & 45.723 & 4 \\
\hline Team Role & 10.210 & 55.933 & 4 \\
\hline Organization Role & 7.452 & 63.386 & 3 \\
\hline Job Role & 6.388 & 69.774 & 4 \\
\hline Innovator Role & 4.620 & 74.395 & 2 \\
\hline \multicolumn{4}{|l|}{ Organizational Commitment } \\
\hline Normative Commitment & 29.270 & 29.270 & 6 \\
\hline Affective Commitment & 17.693 & 46.963 & 4 \\
\hline Continuance Commitment & 14.076 & 61.039 & 5 \\
\hline
\end{tabular}

Source : Survey Data, 2018 


\section{Confirmatory Factor Analysis}

To validate the instrument, a Confirmatory Factor Analysis (CFA) was performed. Subscales of three latent variables (transformational leadership, organizational commitment and employee performance) were included in the measurement model in CFA. The items with low factor loading were dropped from the model as the "useless items" cause the measurement model to have poor fit. After the item has been deleted, new measurement model was run and it was observed intellectual stimulation and idealized influence-attributes were highly correlated (more than 0.85 ) and thus the two constructs are redundant or having serious multicollinearity problem. So one factor, idealized influence-attributes was removed from the model and the new measurement model was run. All factor loadings are significant at 0.001 level. At this stage, the fitness Indexes were not achieved the minimum level and thus Modification Indexes (MI) were considered for "free parameter estimate". Thus the redundant pairs were constrained as "free parameter estimate". Consequently, the results show the acceptable goodness of fit values (Hair, Anderson, Tatham, \& Black, 1998; Kline, 2005). As per the results of CFA, Chi-square $\left(\mathrm{x}^{2} / \mathrm{df}\right)=1.489, \mathrm{CFI}=.96, \mathrm{TLI}=.95$ and $\mathrm{RMSEA}=.041$. The fitness indexes GFI and AGFI are closer to the required level (GFI $=.89$, $\mathrm{AGFI}=.86)$ and thus the model fit is acceptable.

Table 6 summarizes the results of CFA obtained using maximum likelihood estimation method. The standardized estimates of all constructs exceed the level of 0.6 and thus the construct validity achieved. As can be seen in Table 6, Composite Reliability (CR) exceeds the minimum level of 0.6 and Average Variance Explained (AVE) exceeds the minimum level of 0.5 , which proves the internal consistency of scales (Hair et.al., 1998). Convergent validity requirement was satisfied (Joreskog \& Sorbom, 1993) as the standardized loadings for observed variables are above 0.6 and are significant at 0.01 level.

Table 6. Estimates, AVE and CR of the study variables

\begin{tabular}{|c|c|c|c|c|c|c|}
\hline & & & Estimate & AVE & $\mathrm{CR}$ & $\begin{array}{l}\text { Cronbach's } \\
\text { Alpha }\end{array}$ \\
\hline \multicolumn{7}{|c|}{ Transformational Leadership constructs } \\
\hline IN_CO4 & $<---$ & Individualized Consider- $n$ & 0.662 & \multirow[b]{3}{*}{0.534} & \multirow[b]{3}{*}{0.852} & \multirow[b]{3}{*}{.759} \\
\hline IN_CO2 & $<---$ & Individualized Consider- $n$ & 0.844 & & & \\
\hline IN_CO1 & $<---$ & Individualized Consider- $n$ & 0.672 & & & \\
\hline IN_ST3 & $<--$ & Intellectual Stimulation & 0.855 & \multirow[b]{2}{*}{0.548} & \multirow[b]{2}{*}{0.798} & \multirow[b]{2}{*}{.712} \\
\hline IN_ST1 & $<---$ & Intellectual Stimulation & 0.605 & & & \\
\hline IN_MO3 & $<---$ & Inspirational Motivation & 0.794 & \multirow[b]{3}{*}{0.506} & \multirow[b]{3}{*}{0.838} & \multirow[b]{3}{*}{.746} \\
\hline IN_MO2 & $<---$ & Inspirational Motivation & 0.637 & & & \\
\hline IN_MO1 & $<---$ & Inspirational Motivation & 0.695 & & & \\
\hline ID_IN_B4 & $<---$ & Idealized Influence-Behav & 0.661 & \multirow[b]{2}{*}{0.486} & \multirow[b]{2}{*}{0.762} & \multirow[b]{2}{*}{.749} \\
\hline ID_IN_B1 & $<---$ & Idealized Influence-Behav & 0.732 & & & \\
\hline \multicolumn{7}{|c|}{ Employee Performance Constructs } \\
\hline P_CAR4 & $<--$ & Career Role & 0.863 & \multirow{2}{*}{0.699} & \multirow{2}{*}{0.943} & \multirow{2}{*}{.899} \\
\hline P_CAR3 & $<---$ & Career Role & 0.904 & & & \\
\hline
\end{tabular}




\begin{tabular}{|c|c|c|c|c|c|c|}
\hline P_CAR2 & $<--$ & Career Role & 0.867 & & & \\
\hline P_CAR1 & $<---$ & Career Role & 0.695 & & & \\
\hline P_TM4 & $<---$ & Team Role & 0.632 & \multirow{4}{*}{0.547} & \multirow{4}{*}{0.891} & \multirow{4}{*}{.841} \\
\hline P_TM3 & $<---$ & Team Role & 0.706 & & & \\
\hline $\mathrm{P}$-TM2 & $<--$ & Team Role & 0.822 & & & \\
\hline P_TM1 & $<---$ & Team Role & 0.784 & & & \\
\hline P_ORG4 & $<---$ & Organization Role & 0.748 & \multirow{3}{*}{0.779} & \multirow{3}{*}{0.950} & \multirow{3}{*}{.906} \\
\hline P_ORG3 & $<---$ & Organization Role & 0.935 & & & \\
\hline P_ORG2 & $<---$ & Organization Role & 0.95 & & & \\
\hline P_JOB4 & $<---$ & Job Role & 0.678 & \multirow{4}{*}{0.510} & \multirow{4}{*}{0.783} & \multirow{4}{*}{.785} \\
\hline $\mathrm{P} \_\mathrm{JOB} 3$ & $<--$ & Job Role & 0.707 & & & \\
\hline $\mathrm{P} \_\mathrm{JOB} 2$ & $<---$ & Job Role & 0.783 & & & \\
\hline P_JOB1 & $<---$ & Job Role & 0.681 & & & \\
\hline P_INO3 & $<---$ & Innovator Role & 0.806 & \multirow{2}{*}{0.702} & \multirow{2}{*}{0.859} & \multirow{2}{*}{.824} \\
\hline $\mathrm{P}$ INO1 & $<---$ & Innovator Role & 0.869 & & & \\
\hline
\end{tabular}

\begin{tabular}{|c|c|c|c|c|c|c|}
\hline \multicolumn{7}{|c|}{ Organizational Commitment Components } \\
\hline OC_NO6 & $<---$ & Normative Commitment & 0.706 & \multirow[b]{5}{*}{0.557} & \multirow[b]{5}{*}{0.914} & \multirow{5}{*}{.880} \\
\hline OC_NO5 & $<---$ & Normative Commitment & 0.772 & & & \\
\hline OC_NO4 & $<---$ & Normative Commitment & 0.612 & & & \\
\hline OC_NO3 & $<---$ & Normative Commitment & 0.837 & & & \\
\hline OC_NO2 & $<---$ & Normative Commitment & 0.785 & & & \\
\hline OC_AF5 & $<---$ & Affective Commitment & 0.654 & \multirow[b]{4}{*}{0.579} & \multirow[b]{4}{*}{0.903} & \multirow[b]{4}{*}{.850} \\
\hline OC_AF3 & $<---$ & Affective Commitment & 0.836 & & & \\
\hline OC_AF2 & $<---$ & Affective Commitment & 0.865 & & & \\
\hline OC_AF1 & $<---$ & Affective Commitment & 0.666 & & & \\
\hline
\end{tabular}

Note: AVE: Average Variance Extracted; CR: Composite Reliability

Source : Survey Data, 2018

The discriminant validity also was confirmed based on the square root of AVE, the diagonal values of the Table 7. As shown in the table, the square root of AVE is higher than the correlation values in the respective row and column except for very few pairs.

Table 7. Mean, Std. deviation, Correlation and Discriminant Validity

\begin{tabular}{|c|c|c|c|c|c|c|c|c|c|c|c|c|c|}
\hline & Mean & $\begin{array}{c}\text { Std. } \\
\text { Deviati } \\
\text { on }\end{array}$ & $\begin{array}{l}5 \\
0 \\
\Psi_{1} \\
\sum_{1} \\
0 \\
0\end{array}$ & $\begin{array}{l}\sum_{0} \\
\Omega_{0} \\
Z_{1} \\
0 \\
0\end{array}$ & $\begin{array}{l}z \\
0 \\
z \\
a\end{array}$ & $\begin{array}{l}\stackrel{\infty}{\circ} \\
\stackrel{1}{\circ}\end{array}$ & $\begin{array}{l}0 \\
\text { Oै } \\
\text { | }\end{array}$ & 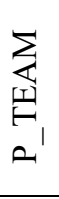 & 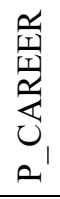 & $\begin{array}{l}n_{1} \\
z_{1} \\
\theta^{\prime}\end{array}$ & $\begin{array}{l}\sum_{1}^{O} \\
Z_{1}\end{array}$ & $\begin{array}{l}\vec{n}_{1} \\
z^{\prime}\end{array}$ & $\begin{array}{l}0 \\
\text { U }\end{array}$ \\
\hline OC_AFFCT & 2.73 & .57 & 0.761 & & & & & & & & & & \\
\hline OC_NORM & 2.51 & .76 & $.169^{* *}$ & 0.746 & & & & & & & & & \\
\hline P_INOV & 3.51 & .78 & .050 & .011 & 0.838 & & & & & & & & \\
\hline P_JOB & 2.94 & .58 & .097 & .032 & $.745^{* *}$ & 0.713 & & & & & & & \\
\hline
\end{tabular}




\section{Ml Macrothink}

International Journal of Human Resource Studies ISSN 2162-3058

\begin{tabular}{|c|c|c|c|c|c|c|c|c|c|c|c|c|c|}
\hline $\mathrm{P} \_\mathrm{ORG}$ & 2.97 & .67 & $.134^{*}$ & $.132^{*}$ & $.648^{* *}$ & $.575^{* *}$ & 0.882 & & & & & & \\
\hline P_TEAM & 2.54 & .49 & .099 & .036 & $.767^{* *}$ & $.700^{* *}$ & $.669^{* *}$ & 0.740 & & & & & \\
\hline P_CAREER & 3.43 & 1.02 & $.140^{*}$ & .111 & $.769^{* *}$ & $.647^{* *}$ & $.505^{* *}$ & $.655^{* *}$ & 0.836 & & & & \\
\hline ID_IN_B & 3.32 & .59 & $.193^{* *}$ & .068 & $.277^{* *}$ & $.298^{* *}$ & $.226^{* *}$ & $.302^{* *}$ & $.215^{* *}$ & 0.697 & & & \\
\hline IN_MO & 3.81 & .92 & $.250^{* *}$ & $.189^{* *}$ & $.350^{* *}$ & $.364^{* *}$ & $.337^{* *}$ & $.346^{* *}$ & $.345^{* *}$ & $.635^{* *}$ & 0.711 & & \\
\hline IN_ST & 3.89 & .67 & $.271^{* *}$ & $.132^{*}$ & $.390^{* *}$ & $.372^{* *}$ & $.382^{* *}$ & $.404^{* *}$ & $.329^{* *}$ & $.856^{* *}$ & $.749^{* *}$ & 0.740 & \\
\hline $\mathrm{IN} \_\mathrm{CO}$ & 2.53 & .62 & $-.16^{* *}$ & -.064 & $-.22^{* *}$ & $-.17^{* *}$ & $-.25^{* *}$ & $-.21^{* *}$ & $-.16^{* *}$ & $-.48^{* *}$ & $-.34^{* *}$ & $-.61^{* *}$ & 0.731 \\
\hline
\end{tabular}

\section{Structural Model}

Before testing hypotheses, the structural model was constructed as shown in Figure 2. In the structural model, most of the fitness indexes achieved the required level and few are very closer to the required level (Chi-square $\left(\mathrm{x}^{2} / \mathrm{df}\right)=1.567, \mathrm{GFI}=.88, \mathrm{AGFI}=.85, \mathrm{CFI}=.94$, $\mathrm{TLI}=.94, \mathrm{IFI}=.93$ and $\mathrm{RMSEA}=.045)$ and thus the model fit is acceptable.

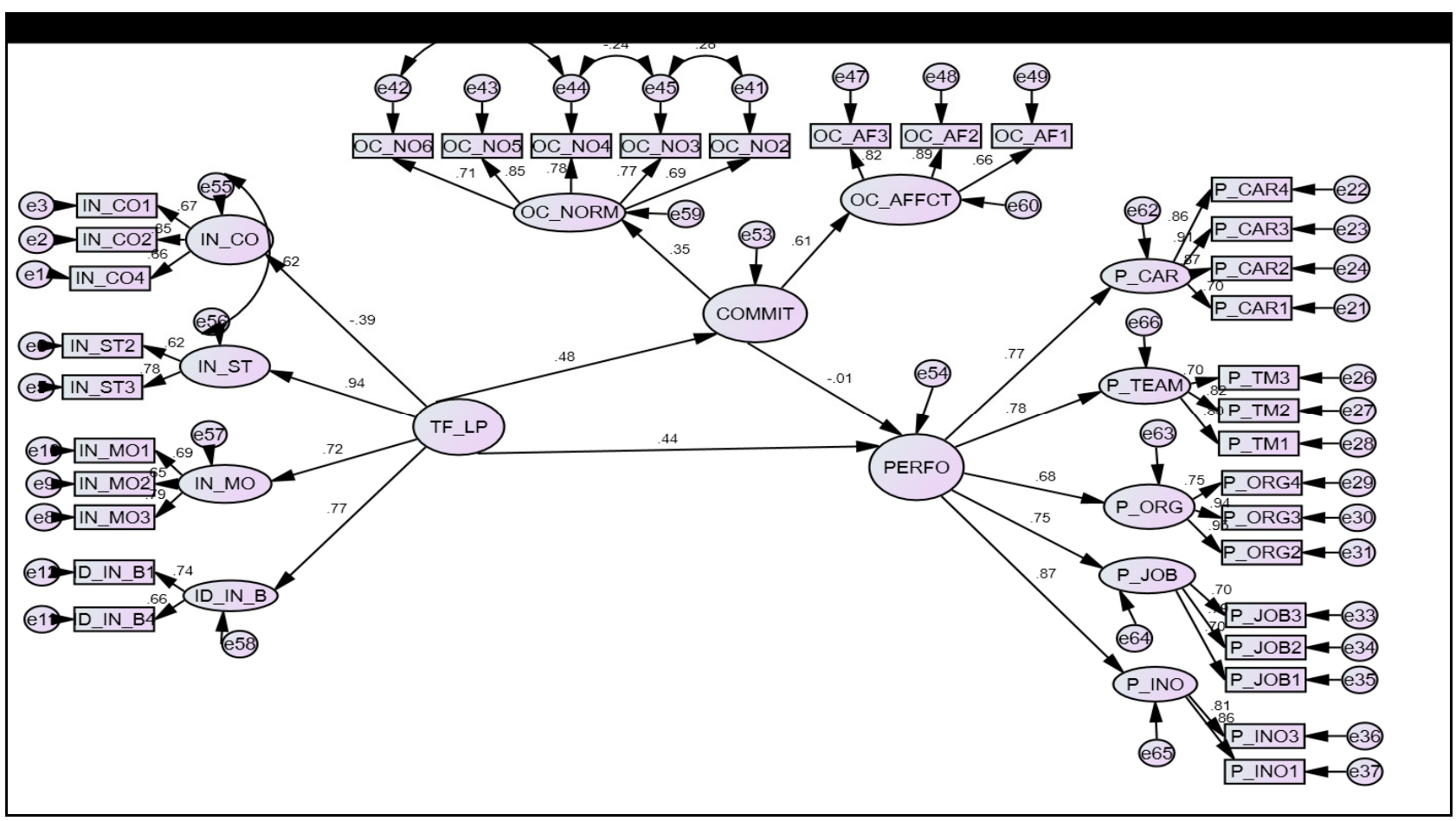

Figure 2. Structural Equation Model

Notes: TF_LP -Transformational Leadership; PERFO- Employee Performance; COMMITOrganizational Commitment; IN_CO- Individualized Consideration, IN_ST- Intellectual Stimulation; IN_MO- Inspirational Motivation; ID_IN_B - Idealized Influence- Behviour; OC_NORM - Normative Commitment; OC_AFFECT - Affective Commitment; P_CAR -Performance-career role; P_TEAM - Performance-team role; P_ORG - 
Performance-organization role; $\quad$ P_JOB $\quad-$ Performance-job role; P_INO Performance-innovator role

After validating the measurement models for each variable, the structural equation model was constructed as shown in the Figure 2. For the structural model, most of the Fitness Indexes achieved required level and, GFI and AGFI are closer to the required level (Chi-square $=.000$, $\mathrm{CMIN} / \mathrm{DF}=1.567, \mathrm{GFI}=.87, \mathrm{AGFI}=.84, \mathrm{CFI}=.94, \mathrm{TLI}=.94, \mathrm{IFI}=.94, \mathrm{RMSEA}=.045)$ and thus the model fit is acceptable.

Table 8. Effects of variables

\begin{tabular}{|c|c|c|c|c|c|}
\hline & $\begin{array}{l}\text { Unstandar } \\
\text { dized } \\
\text { Estimate }\end{array}$ & $\begin{array}{l}\text { Standardi } \\
\text { zed } \\
\text { Estimate }\end{array}$ & S.E. & $\mathrm{P}$ & Results \\
\hline $\begin{array}{l}\text { Direct Effect } \\
\text { Transformational } \quad \text { Leadership } \rightarrow \\
\text { Employee Performance }\end{array}$ & .65 & .43 & .135 & $* * *$ & H1 -Supported \\
\hline $\begin{array}{l}\text { Transformational Leadership } \rightarrow \\
\text { Organizational Commitment }\end{array}$ & .26 & .48 & .117 & .026 & H2 -Supported \\
\hline $\begin{array}{l}\text { Organizational Commitment } \rightarrow \\
\text { Employee Performance }\end{array}$ & -.03 & -.012 & .362 & .925 & H3 - Not Supported \\
\hline $\begin{array}{ll}\text { Mediating Effect } & \\
\text { Transformational Leadership } & \rightarrow \\
\text { Organizational Commitment } & \rightarrow \\
\text { Employee Performance } & \end{array}$ & .69 & .44 & .179 & $* * *$ & H4 - Not Supported \\
\hline
\end{tabular}

*** 0.001 level

Source: Survey data

As can be seen in Table 8, the direct effect of transformational leadership on performance before mediation is 0.65 and the effect is significant $(p=.000)$. Therefore, the Hypothesis 1 is supported.

The direct effect of transformational leadership on organizational commitment is 0.26 and the effect is significant ( $\mathrm{p}=0.026$ ). Based on the results, the Hypothesis 2 is supported.

The direct effect of organizational commitment on performance is -0.03 and the effect is not significant ( $\mathrm{p}=0.925$ ). Thus, the Hypothesis 3 is not supported.

The indirect (mediated) effect of transformational leadership on performance is 0.69 and the effect is significant at .001 level. But the direct effect before mediation is 0.65 (significant at .001 level). As the direct effect after mediation has increased, it can be concluded that there is no mediation effect. Thus, organizational commitment doesn't mediate the effect of transformational leadership on Employee performance. Therefore, the Hypothesis 4 is not 
supported.

\section{Discussion}

The study revealed that the transformational leadership has a significant positive impact on employee performance. The current research findings are consistent with previous studies (Kehinde \& Banjo, 2014; Pradeep \& Prabhu, 2011; Tsigu \& Rao, 2012; Gimuguni et al., 2014; and Pradeep \& Prabhu, 2011). The positive effect of transformational leadership style on organizational commitment is also in line with the previous studies (Abdul, Ausnain \& Munawar, 2012; Greenburg \& Baron, 2009; Bass \& Avolio, 1994; and Lo, Ramayah \& Min, 2009).

In addition, as per the results of the study, the effect of organizational commitment on employee performance is not statistically significant. The result is not consistent with previous research findings (Chen, Silverthrone \& Hung, 2006, and Rashid, Sambasvani, and Joari, 2003). The inconsistent results of the relationship between commitment and employee performance could be due to the context and sector where the study was undertaken. The survey participants are from government sector and, even though the people commit to their job, their performance could be low due to various reasons such as stress, uninterested tasks, inadequate resources to perform their job and so on. Thus, the perceived performance of employees could be low or high regardless of their commitment levels.

The major focus of the study is to test the mediating effect of organizational commitment in the effect of transformational leadership on employee performance. The results show that organizational commitment doesn't mediate the effect of transformational leadership on employee performance. The finding of the current study is not consistent with the reported results of Ying and Ahmad (2009), Wang (2006) and Chi, Tsai and Chang (2007). In the current study, as the impact of organizational commitment on employee performance is statistically not significant, we could expect no mediating effect of organizational commitment.

The present study gives an insight regarding the need for adopting transformational leadership by managers in the Divisional Secretariats which are responsible for providing better services to the public and for the regional development.

\section{Conclusion and Implications}

Transformational leadership has attracted the attention of many researchers in the fied of management. The present study was aimed at identifying the impact of transformational leadership on employee performance and the mediating effect $f$ organizational commitment in the relationship between them among the employees of Divisional Secretariats in Jaffna District. The results revealed that transformational leadership is a predictor of employee performance and, organizational commitment doesn't mediate the effect of transformational leadership on employee performance. It is believed that this study will be helpful for the leaders and administrators in the public sector. Based on the findings, the leaders of the Divisional Secretariats need to pay more attention in their leadership style as a way to boost employee performance and commitment levels. As public service is given much important for 
promoting the life of community people and the regional development, adopting appropriate leadership becomes vital.

The findings of this research will be useful for future researchers, students and academicians to understand the effect of transformational leadership style on employee performance. The public sector organizations will be able to use the findings of this research to develop leadership programmes that will help the leaders acquire relevant leadership skills. The findings will also help leaders in recognizing the most appropriate leadership style to enhance employee performance.

\section{Directions for Future Research}

The findings of this study revealed that transformational leadership predicts job performance of employees, at the same time, organizational commitment doesn't mediate the relationship between them. This study adds to the body of knowledge in the field of leadership, however, there are still a number of limitations. Particularly, the transformational leadership style was taken for investigation in the present study and thus the other styles such as transactional and laissez-faire leadership could be considered by future researchers. In addition, this study was conducted in the Divisional Secretariats in Jaffna District. The study could be extended to other regions and other public sector organizations including larger samples to find the leadership style that predicts employee performance and the factors mediating the effect of leadership on employee performance. In addition, the relative influence of each of the five dimensions (subscales) of transformational leadership on employee performance also should be explored to better understand what dimension of transformational leadership could result in enhanced performance.

Another major focus of future researchers should be on the mediating factors in the leadership-performance relationship. In the current study, we found that organizational commitment doesn't mediate the effect of transformational leadership on employee performance and thus, other potential mediators need to be identified by future researchers. Among various employee behaviour dimensions, performance was investigated in the current study and therefore, future researchers need to investigate the influence of transformational leadership on other dimensions of employee behaviours like time management, conduct at work, attendance, job satisfaction, organizational citizenship behaviour, etc among the employees of the Divisional Secretariats and in other sectors at large.

As there are not adequate studies in the public sector in Sri Lanka, more research should follow with different samples from various sectors, types of businesses and in different regions. Comparative studies also may be conducted to find out differences based on sectors, types of businesses, locations, etc.

\section{Acknowledgement}

We are grateful for the Divisional Secretaries of the selected Divisional Secretariats in Jaffna District for their fullest support in collecting data from the employees for this research. We are also thankful for the participants of this research for their cooperation and for completing the survey questionnaires. 


\section{References}

Abdul, Q. C., Ausnain, J., \& Munawar, S. (2012). The impact of transformational and transactional leadership styles on the motivation of employees in Pakistan. Pakistan economic and social review, 50(2), 223-231.

Aboshaiqah, A. E., Hamdan-Mansour, A. M., Sherrod, D. R., Alkhaibary, A., \& Alkhaibary, S. (2014). Nurses' Perception of Managers' Leadership Styles and Its Associated Outcomes. American Journal of Nursing Research, 2(4), 57-62.

Andersen, J. A. (2016). An old man and the "sea of leadership". Journal of Leadership Studies, 9(4), 70-81. https://doi.org/10.1002/jls.21422

Avolio, B. J., \& Yammarino, F. J. (2002). Introduction to, and overview of, transformational and charismatic leadership. In B. J. Avolio \& F.J. Yammarino (Eds.).

Avolio, B. J., Bass, B. M., \& Jung, D. I. (1999). Re-examining the components of transformational and transactional leadership using the Multifactor Leadership Questionnaire. Journal of Occupational and Organizational Psychology, 72, 441-462. https://doi.org/10.1348/096317999166789

Avolio, B. J., Zhu, W., Koh, W., \& Puja, B. (2004). Transformational leadership and organizational commitment: Mediating role of psychological empowerment and moderating role of structural distance. Journal of Organizational Behavior, 24(1), 1-18. https://doi.org/10.1002/job.283

Basham, L. M. (2012). Transformational and transactional leaders in higher education. SAM Advanced Management, Spring, 15-37.

Bass, B. M., \& Avolio, B. J. (2000). MLQ Multifactor Leadership Questionnaire sample set: Technical report, leaders form, rater form, and scoring key for MLQ From 5x-Short. (2nd ed). Redwood City, CA: Mind Garden.

Bass, B. M. (1985). Leadership and performance beyond expectations. New York: Free Press.

Bass, B. M., Waldman, D. A., Avolio, B. J., \& Bebb, M. (1987). Transformational leadership and the falling dominoes effect. Group and Organization Studies, 12, 73-87. https://doi.org/10.1177/105960118701200106

Bass, B. M., \& Avolio, B. J. (1994). Improving organizational effectiveness through transformational leadership. Thousand Oaks: Sage Publications.

Barbuto, J. E. (2005). Motivation and transactional, charismatic, and transformational leadership: A test of antecedents. Journal of Leadership \& Organizational Studies, 11(4), 26-40. https://doi.org/10.1177/107179190501100403

Bolden, R., Gosling, J., O’Brien, S., Peters, K., Ryan, M., \& Haslam, A. (2012). Academic leadership: changing conceptions, identities and experiences in UK higher education. Leadership Foundation for Higher Education, University of Exeter, UK. 
Bono, J. E., \& Judge, T. A. (2003). Self-concordance at work: Toward understanding the motivational effects of transformational leaders. Academy of Management Journal, 46, 554-571.

Burns, J. M. (1978). Leadership. New York : Harper Torchbooks.

Chan, S. H. (2010). The influence of leadership expertise and experience on organizational performance: a study of Amanah Ikhtiar Malaysia. Asia Pacific Business Review, 16(1-2), 59-77. https://doi.org/10.1080/13602380802503566

Chen, J., Silverthorne, C., \& Hung, J. (2006). Organization communication, job stress, organizational commitment, and job performance of accounting professionals in Taiwan and America. Leadership \& Organization Development Journal, 27(4), 242-249. https://doi.org/10.1108/01437730610666000

Chi, H., Tsai, H., \& Chang, P. (2007). Investigating the relationship among leadership styles, emotional intelligence and organization commitment on job performance: A study of salespeople in Thailand. The Journal of Human Resource and Adult Learning, 3(2), 199-212.

Child, D. (2006). The Essentials of Factor Analysis. ( $3^{\text {rd }}$ ed). New York: Continuum.

Cole, G. A. (2005). Personnel and Human Resource Management. London: ELST Publishers.

Conger, J. A., \& Kanungo, R. N. (1998). Charismatic leadership in organizations. Thousand Oaks, CA: SAGE.

Dhammika, K. A. S. (2013). Measuring Employees' Performance in the Public Sector in Sri Lanka: Testing of Two Models. Kelaniya Journal of Human Resource Management, 8(1), 1-20. https://doi.org/10.4038/kjhrm.v8i1.1

Dvir, T., Eden, D., Avolio, B., \& Shamir, B. (2002). Impact of transformational leadership on follower development and performance: a field experiment. Academy of Management Journal, 45, 735-744.

Field, A. (2013). Discovering Statistics using SPSS, $\left(4^{\text {th }}\right.$ ed). London: SAGE.

Fuller, E. L., \& Hemmerle, W. J. (1966). Robustness of the maximum-likelihood estimation procedure in factor analysis. Psychometrika, 31(2), 255-266. https://doi.org/10.1007/BF02289512

George, D., \& Mallery, M. (2010). SPSS for Windows Step by Step: A Simple Guide and Reference, 17.0 update $\left(10^{\text {th }}\right.$ ed.) Boston: Pearson.

Gimuguni, L., Nandutu, J., \& Magolo, A. (2014). Effect of leadership styles on performance of local governments in Uganda, A case of Mbale District.

Gong, Y. P., Hung, C. J., \& Farh, J. L. (2009). Employee learning orientation, transformational leadership, and employee creativity: The mediating role of employee creative self-efficacy. Academy of Management Journal, 52, 765-778. https://doi.org/10.5465/amj.2009.43670890 
Gottfredson, R. K., \& Aguinis, H. (2017). Leadership behaviors and follower performance: deductive and inductive examination of theoretical rationales and underlying mechanisms. Journal of Organizational Behaviour, 38, 558-591. https://doi.org/10.1002/job.2152

Greenberg, J., \& Baron, R. (2009). Behaviour in Organizations, (9th ed). India: Pearson Prentice Hall Publication.

Hair, J. F., Anderson, R. E., Tatham, R. L., \& Black, W. C. (1998). Multivariate data analysis (5th ed.). Upper Saddle River, NJ: Prentice Hall.

Hater, J. J., Bass, B. M. (1988). Superiors' evaluations and subordinates' perceptions of transformational and transactional leadership. Journal of Applied Psychology, 73(4) 695-702. https://doi.org/10.1037/0021-9010.73.4.695

Hemakumara, M. G. G. (2011). Leadership Styles And Team Cohesiveness: A Study Based On Non Managerial Level Employees In Public Sector Organizations In Sri Lanka. International Research Conference on Management and Finance, University of Colombo Retrieved from http://archive.cmb.ac.lk:8080/research/handle/70130/1631. [Accessed 1 Aug 2017].

Herbst, T. H. H., \& Conradie, P. D. P. (2011). Leadership effectiveness in higher education: managerial self perceptions versus perceptions of others. South African Journal of Psychology, 37(1), 1-14.

Howell, J. M., \& Hall-Merenda, K. E. (1999). The ties that bind: The impact of leadermember exchange, transformational and transactional leadership, and distance on predicting follower performance. Journal of Applied Psychology, 84, 680-694. https://doi.org/10.1037/0021-9010.84.5.680

Ispas, A., \& Babaita, C. (2012). The effects of leadership style on the Employees' Job satisfaction and Organizational commitment from the Hotel Industry. Approaches in Organizational Management, 15(16), 254-262.

Jong, J., \& Hartog, D. (2007). How leaders influence employees' innovative behavior. European Journal of Innovation Management, 10(1), 41-64. https://doi.org/10.1108/14601060710720546

Jöreskog, K. G., \& Sörbom, D. (1979). Advances in factor analysis and structural equation models. Cambridge, MA: Abt Books.

Kaiser, H. F. (1974). An index of factorial simplicity. Psychometrika, 39(1), 31-36. https://doi.org/10.1007/BF02291575

Kehinde, O. A., \& Banjo, H. A. (2014). A test of the impact of leadership styles on employee performance: A study of department of petroleum resources. International Journal of Management Sciences, 2(3), 149-160.

Kline, R. B. (2005). Principles and practice of structural equation modeling (2nd ed.). New 
York: Guilford Press.

Liao, H., \& Chuang, A. C. (2007). Transforming service employees and climate: A multilevel, multisource examination of transformational leadership in building long-term service relationships. Journal of Applied Psychology, 92, 1006-1019. https://doi.org/10.1037/0021-9010.92.4.1006

Lo, M., Ramayah, T., \& Min, H. (2009). Leadership styles and organizational commitment: A test on Malaysia manufacturing industry. African Journal of Marketing Management, 1, 133-139. Retrieved from http://www.academicjournals.org/ajmm. [accessed 16 April 2015]

Lok, P., \& Crawford, J. (2004). The effect of organizational culture and leadership style on job satisfaction and organizational commitment: A cross-national comparison. Journal of Management Development, 23(4), 321-338. https://doi.org/10.1108/02621710410529785

Lopez-Dominguez, M., Enache, M., Sallan, J., \& Simo, P. (2014). Transformational leadership as an antecedent of change oriented organizational citizenship behavior, Journal of Business Research, 66(10), 2147-2152. https://doi.org/10.1016/j.jbusres.2013.02.041

Nel, P. S., Haasbroek, G. D., Schultz, H. B., Sono, T., \& Werner, A. (2004). Human resources management. (6th ed.) New York: Oxford University Press.

Ng, T. W. (2017). Transformational leadership and performance outcomes: analyses of multiple mediation pathways. Leadership Quarterly, 28, 385-417. https://doi.org/10.1016/j.leaqua.2016.11.008

Nunnally, J. C. (1978). Psychometric theory. New York: McGraw -Hill.

Meyer, J., \& Allen N. (1997). Commitment in the workplace, Theory, research and application. Thousand Oaks, CA: Sage.

Pradeep, D. D., \& Prabhu, N. R. V. (2011). The relationship between effective leadership and employee performance. Journal of Advancements in Information Technology, 20, 198-207.

MacKenzie, S. B., Podsakoff, P. M., \& Rich, G. A. (2001). Transformational and transactional leadership and salesperson performance. Journal of the Academy of Marketing Science, 29, 115-134. https://doi.org/10.1177/03079459994506

Podsakoff, P. M., MacKenzie, S. B., \& Bommer, W. H. (1996). Transformational leader behaviors and substitutes for leadership as determinants of employee satisfaction, commitment, trust, and organizational citizenship behaviors. Journal of Management, 22, 259-298. https://doi.org/10.1177/014920639602200204

Raja, A., \& Palanichamy, P. (2012). Leadership styles and its impact on organisational commitment. The Journal of commerce, 3(4), 15-23.

Rashid, Z. A., Sambasivan, M., \& Johari, J. (2003). The influence of corporate culture and organizational commitment on performance. Journal of Management Development, 22(8), 708-728. https://doi.org/10.1108/02621710310487873 
Rasool, H. F., Arfeen, I. U., Mothi, W., \& Aslam, U. (2015). Leadership styles and its impact on employee's performance in health sector of Pakistan. City University Research Journal, 5(1), 97-109.

Samuels, P. (2016). Advice on exploratory factor analysis. DOI: 10.13140/RG.2.1.5013.9766 https://www.researchgate.net/publication/319165677_Advice_on_Exploratory_Factor_Analy sis [accessed Dec 012018 ].

Sani, A., \& Maharani, V. (2012). The impact of transformational leadership and organizational commitment on job performance among lecturers of faculty in the Islamic Maulana Malik Ibrahim Malang university the mediating effects of organisational citizenship behavior. International Journal of Academic Research, 4(4), 102-106. https://doi.org/10.7813/2075-4124.2012/4-4/B.15

Sekaran, U. (1992) Research methods for business: a skill building approach. (2 ${ }^{\text {nd }}$ ed.) New.

Shamir, B., House, R. J., \& Arthur, M. B. (1993). The motivational effects of charismatic leadership: A self-concept based theory. Organizational Science, 4, 557-594. https://doi.org/10.1287/orsc.4.4.577

Streiner, D. L. (1994). Figuring out factors: the use and misuse of factor analysis. The Canadian of Journal Psychiatry, 39(3), 135-140. https://doi.org/10.1177/070674379403900303

Tsigu, G. T., \& Rao, D. P. (2015). Leadership styles: their impact on job outcomes in Ethiopian banking industry. ZENITH International Journal of Business Economics \& Management Research, 5(2), 41-52.

Vinger, G. (2009). The restructuring of a university: a call for the exhibition of transformational leadership behaviours. The International Journal of Learning, 16(10), 267-286. https://doi.org/10.18848/1447-9494/CGP/v16i10/46675

Wallace, J. C., Edward, B. D., Arnorld, T., \& Frazier, L. M. (2009). Work stress, role-based performance and the moderating influence of organizational support. Journal of Applied Psychology, 94(1), 254-262. https://doi.org/10.1037/a0013090

Wayne, S., Liden, R., \& Sparrowe, R. (2000). An examination of the mediating role of psychological empowerment on the relations between the job, interpersonal relationships, work outcomes. Journal of Applied Psychology, 85, 407-416. https://doi.org/10.1037/0021-9010.85.3.407

Welbourne, T. M., Johnson, D. E., \& Erez, A. (1998). The role-based performance scale: validity analysis of a theory-based measure. Academy of Management Journal, 41(5), 540-555.

Wijesiri, L. (2016). Turning towards an effective and efficient public service, Daily News. (2016 Feb 1) Retrieved from http://dailynews.lk/2016/02/01/features/turning-towards-effective-and-efficient-public-service [accessed 10 July 2017]. 
Yeh, H., \& Chien, S. (2012). The mediating Effect of Organizational Commitment on Leadership Type and Job Performance. The Journal of Human Resource and Adult Learning, $8(2), 50-59$.

Yiing, L. H., Zaman, K., \& Ahmad, B. (2009). The moderating effects of organizational culture on the relationships between leadership behaviour and organizational commitment and between organizational commitment and job satisfaction and performance. Leadership \& Organization Development Journal, 30(1), 53-86. https://doi.org/10.1108/01437730910927106

Yousef, D. A. (2000). Organizational commitment: A mediator of the relationships of leadership behavior with job satisfaction and performance in a non-western country. Journal of managerial Psychology, 15(1), 6-24. https://doi.org/10.1108/02683940010305270

Zhu, W., Avolio, B. J., \& Walumbwa, F. O. (2009). Moderating role of follower characteristics with transformational leadership and follower work engagement. Group \& Organization Management, 34, 590-619. https://doi.org/10.1177/1059601108331242

\section{Copyright Disclaimer}

Copyright for this article is retained by the author(s), with first publication rights granted to the journal.

This is an open-access article distributed under the terms and conditions of the Creative Commons Attribution license (http://creativecommons.org/licenses/by/4.0/). 